\title{
Research Paper: \\ Protective Role of Leptadenia Hastata on the Haematological and Biochemical Alterations in Adrenaline-Induced Hypertensive Rats
}

\author{
Adewuyi Hassan Abdulsalam ${ }^{1 *}$ (D), Muhammad L. Hadiza ${ }^{1}$ (D), Onukogu Stella Chiamaka ${ }^{1}$, Ibrahim Jonathan ${ }^{2}$ (D, Suleiman Alfa ${ }^{3}$ (D), Alawode Rah-
} matallah Adenike ${ }^{4}$ (D), Umar Sherif Itopa ${ }^{5}$ (iD)

${ }^{1}$. Department of Biochemistry, School of Life Sciences, Federal University of Technology, Minna, Nigeria.

2. Department of General Study, Gombe State College of Health, Sciences and Technology, Kaltungo, Nigeria.

3. Department of Biological Sciences, School of Applied and Natural Sciences, Federal Polytechnic Bida, Niger State, Nigeria.

4. Forestry Research Institute of Nigeria-Southern, Guinea Research Station, Mokwa, Niger State, Nigeria.

5. Department of Science and Laboratory Technology, Federal Polytechnic, Ile-Oluji, Nigeria. Role of Leptadenia Hastata on the Haematological and Biochemical Alterations in Adrenaline-Induced Hypertensive Rats. Iranian Journal of Toxicology. 2020; 14(1):25-32. http://dx.doi.org/10.32598/ijt.14.1.25

\section{(1) (8)}

Article info:

Received: 24 Jul 2019

Accepted: 25 Nov 2019

Online Published: 10 Jan 2020

* Corresponding author:

Adewuyi Hassan Abdulsalam, MSc. Address: Department of Biochemistry, Federal University of Technology

Minna, Nigeria.

E-mail: hasselbatch@gmail.com

\section{A B ST RACT}

Background: Leptadenia hastata (L. Hastata) is a plant used for various diseases in Nigeria. This study evaluated the protective effects of $L$. Hastate on the haematological and biochemical alterations in adrenaline-induced hypertensive rats.

Methods: Twenty-five rats were divided equally into five groups (A-E). Groups A-D were given $0.5 \mathrm{mg} / \mathrm{kg}$ adrenaline, groups $A$ and $B$ were treated with 100 and $200 \mathrm{mg} / \mathrm{kg}$ the extract of L. Hastata, respectively, while groups $C$ and D were treated with $5 \mathrm{mg} / \mathrm{kg}$ amlodipine (standard control) and normal saline (untreated control), respectively. Group E were given distilled water (normal controls). The adrenaline was injected intraperitoneally while the extract was given orally once daily for seven days.

Results: Treatment with 100 and $200 \mathrm{mg} / \mathrm{kg}$ of the extract significantly reduced the elevated serum albumin, ALP, ALT, AST, chloride, sodium and creatinine, cholesterol and LDL concentrations compared with the untreated hypertensive rats. The bicarbonate level, WBC and $\mathrm{RBC}$ counts, mean cell hemoglobin and packed cell value were higher in rats treated with the extract compared with the untreated hypertensive rats. The mean cell value, HDL, triglyceride, urea, potassium, total and direct bilirubin concentrations in experimental groups were not significantly different from those in the controls $(\mathrm{P}<0.05)$.

Conclusion: Our results suggest that treatment of the hypertensive rats with the extract of L. Hastata protects against renal, hepatic and cardiac damages, thus it could be considered as a natural anti-hypertensive agent. Further studies are required to identify the bioactive constituents and the mechanism(s) of action.

Keywords: Adrenaline; Biochemical; Haematological; Lipid profile; Leptadenia hastata

\section{Introduction}

ardiovascular diseases, such as hypertension, arteriosclerosis and heart disease, are prevalent in developed countries, with increasing numbers of people showing the associated symptoms [1]. High blood pressure is a common disorder in developing countries, such as Nigeria, which if not effectively treated, results in a greatly increased probability of coronary thrombosis, stroke and renal failure [2]. Hypertension can be caused by many factors, including increases in the volume of body fluid, increased blood vessel walls resistance, and other factors that elevate blood pressure [3]. 
Treatment of hypertension reduces cardiovascular risks, and this has been a major focus of campaigns aimed at reducing the associated morbidity and mortality [4]. Because of the high incidence of the morbidities, many new drugs have been introduced which may provide high efficacy but are not without side effects. Natural products particularly from medicinal plants provide a large diversity of safe bioactive agents against some diseases [5]. Recently, attention has been paid to herbal products, which are traditionally used as potential therapeutic agents in the prevention and management of cardiovascular disease [6].

The edible plant, L. Hastata (Asclepiadaceae) with creeping latex stems, glabrescent leaves, glomerulus and racemes flowers, is known in some West African countries for its various health applications [7]. This plant is mostly used in Nigeria among Higgi's in the north east and the Hausa's in the north central areas as the source of spices, sauces, and medicinal purposes by local traditional healers. The leaf extract from L. Hastata has been used to treat onchocerciasis (river blindness), a parasitic tropical disease in Mali [8]; scabies in Chad [9]; hypertension, catarrh (excessive inflammatory discharge of mucus in the nose or throat), and skin diseases in Nigeria [10].

Phytochemical study on L. Hastate leaves has found phenolic glycosides, tannins, flavonoids, proanthocyanidins, alkaloids and saponins in this plant [11]. Generally, certain enzymes and biochemical parameters, including creatinine, are important biomarkers of myocardial ischemia due to hypertension [6]. To the best of available knowledge, there is no report in the literature on the antihypertensive property of $L$. Hastata leaves extract. The purpose of this study was to investigate the effect of $L$. Hastata extract on the biochemical and haematological parameters in adrenaline-induced hypertensive rats.

\section{Materials and Methods}

Sample Collections: Fresh samples of leaves from L. Hastata plant were collected in Bosso, Minna, Niger state, Northern Nigeria.

Chemicals and Reagents: The biochemical assay kits for AST, ALT, ALP, total proteins, albumin, urea, creatinine and electrolytes were purchased from Randox Liquizyme (Crumlin, UK). The kits for total cholesterol, triglycerides and HDL assays were obtained from Agape Diagnostics Ltd. (Cham, Switzerland).

Experimental Animals: Twenty five adult rats weighing $120.78 \pm 5$ grams were obtained from the Animal
Holding Unit, School of Life Sciences, Federal University of Technology, Minna, Nigeria. They were kept and used in compliance with the internationally accepted principles for the handling and use of laboratory animals as contained in the Canadian council on Animal Care Guidelines and the Review Protocol.

Sample Extraction: The leaves were thoroughly washed under tap water to remove the contaminants after which they were cut into pieces, dried for 2 weeks at $37^{\circ} \mathrm{C}$ and finally grounded. A $50 \mathrm{~g}$ of the ground plant material was extracted with $200 \mathrm{ml}$ of chloroform, using Soxhlet apparatus and the resulting extract was concentrated on a rotary evaporator.

Experimental Design: The 25 rats were divided into 5 groups (A-E) of 5 rats each and were assigned as follows:

Group A: Rats receiving normal saline only (normal).

Group B: Untreated, adrenaline-induced hypertensive rats.

Group C: Rats receiving adrenaline $(0.5 \mathrm{mg} / \mathrm{kg})$ and amlodipine $(5 \mathrm{mg} / \mathrm{kg})$ (standard)

Group D: Rats receiving adrenaline $(0.5 \mathrm{mg} / \mathrm{kg})$ and the extract $(100 \mathrm{mg} / \mathrm{kg})$.

Group E: Rats receiving adrenaline $(0.5 \mathrm{mg} / \mathrm{kg})$ and the extract $(200 \mathrm{mg} / \mathrm{kg})$.

The extract was given to the rats orally, but adrenaline and amlodipine were administered intraperitoneally once daily for seven consecutive days.

Collection of Blood and Serum: After the study period, the animals were sacrificed under ether anaesthesia and the blood was collected into EDTA bottles for haematological analyses. Another set of blood samples was collected in EDTA-free bottles, and were allowed to cloth followed by centrifugation at $3000 \mathrm{rpm}$ for $10 \mathrm{~min}$ utes $[12,13]$. The plasma samples were collected and kept in a freezer $\left(-20^{\circ} \mathrm{C}\right)$ until further analyses.

Analyses of Biochemical Parameters: Parameters, such as transaminases [14] total proteins [15], albumin and bilirubin [16], urea, creatinine and electrolytes from the serum samples were assayed, using standard protocols $[17,18]$. The serum concentrations of total cholesterol, triglycerides and HDL were assayed by enzymatic and colorimetric methods, using commercial kits according to the manufacturer's guidelines. VLDL was 
estimated as TG/5 and LDL was calculated using Friedewald formula [19] as follows:

$$
L D L(m g / d l)=T C-(H D L+V L D L) .
$$

Analyses of Haematological Parameters: The hematological parameters were determined for Hemoglobin ( $\mathrm{Hb}$ ), Packed Cell Value (PCV), Red Blood Cells (RBC), White Blood Cells (WBC), Mean Corpuscular Volume (MCV) and Mean Corpuscular Hemoglobin Concentration (MCHC), using an automated hematologic analyzer (SYSMEX KX21, Japan) based on the methods described by Dacie and Lewis [20].

Statistical Analyses: The data were statistically analyzed as the Means \pm SD. One-way analysis of variance and Duncan's multiple regression test were used for group comparisons at the $\mathrm{P}<0.05$ significance level.

\section{Results}

Haematological Parameters: The $\mathrm{WBC}$ and $\mathrm{RBC}$ counts, mean hemoglobin concentration, and packed cell value were significantly lower $(\mathrm{P}<0.05)$ in adrenaline-induced hypertensive but untreated rats compared with the normal controls. Treatment of rats with the extract $L$. Hastata and amlodipine significantly increased $(\mathrm{P}<0.05)$ the concentrations of the haematological parameters compared with those in the untreated controls. However, the mean cell values were similar in all experimental groups compared with that in the controls (Figure 1).
Electrolytes, Urea and Creatinine: The serum chloride, sodium and creatinine concentrations were significantly higher $(\mathrm{P}<0.05)$ in adrenaline-induced hypertensive but untreated rats compared with the normal controls. Treatment of rats with the extract and amlodipine significantly decreased $(\mathrm{P}<0.05)$ the concentrations of chloride, sodium and creatinine compared with those in the untreated controls. The serum bicarbonate concentration was lower in the adrenaline-induced hypertensive but untreated rats compared with both the treated groups and the normal controls. The serum urea and potassium concentrations were similar in all experimental groups compared with the controls (Figure 2).

Biochemical Parameters: The serum albumin, ALP, ALT and AST levels in adrenaline-induced hypertensive but untreated rats were significantly higher compared with those in the normal controls. Treatment of rats with the extract and amlodipine significantly decreased $(\mathrm{P}<0.05)$ the levels of these parameters compared with the untreated controls. The serum total proteins concentration was significantly lower $(\mathrm{P}<0.05)$ in the adrenaline-induced hypertensive but untreated rats compared with those in the treated and control rats. The serum total and direct bilirubin levels were similar in all experimental groups compared with the controls.

Lipid Profile: HDL-cholesterol and triglyceride concentrations in rats treated with 100 and $200 \mathrm{mg} / \mathrm{kg}$ of the extract were not significantly different $(\mathrm{P}<0.05)$ from those in the untreated and normal control groups. Total cholesterol and LDL concentrations were significantly higher

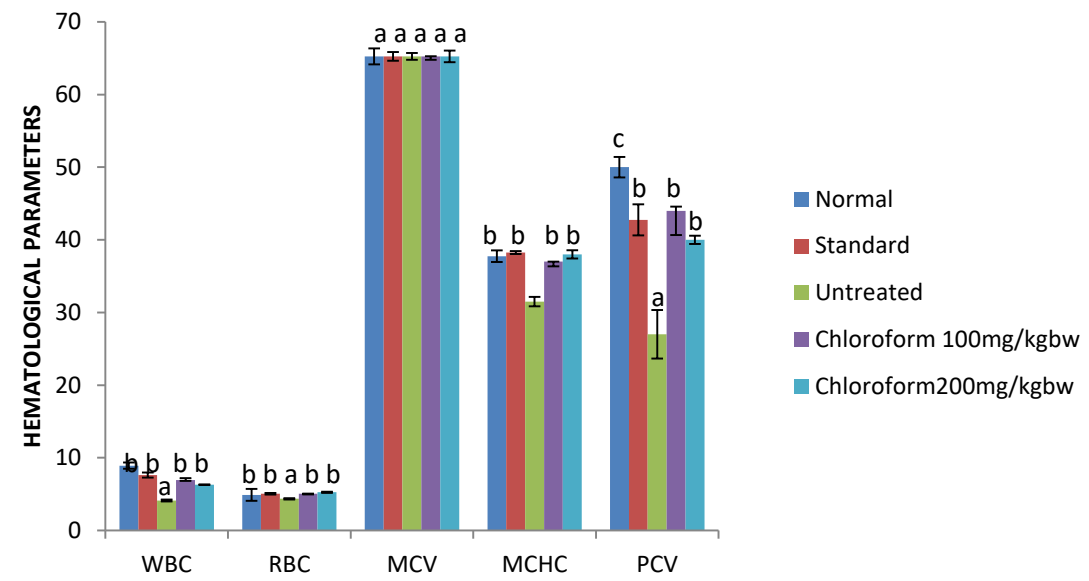

Figure 1. Effect of the extract of L. Hastata leaves on the hematological parameters in adrenaline-induced hypertensive, untreated rats.

Keys: WBC: White blood cells; RBC: Red blood cells

MCV: Mean corpuscular volume; MCHC: Mean corpuscular hemoglobin counts; PCV: Packed Cell Value

Bars with different superscript alphabets were significantly different $(c>b>a)$. 


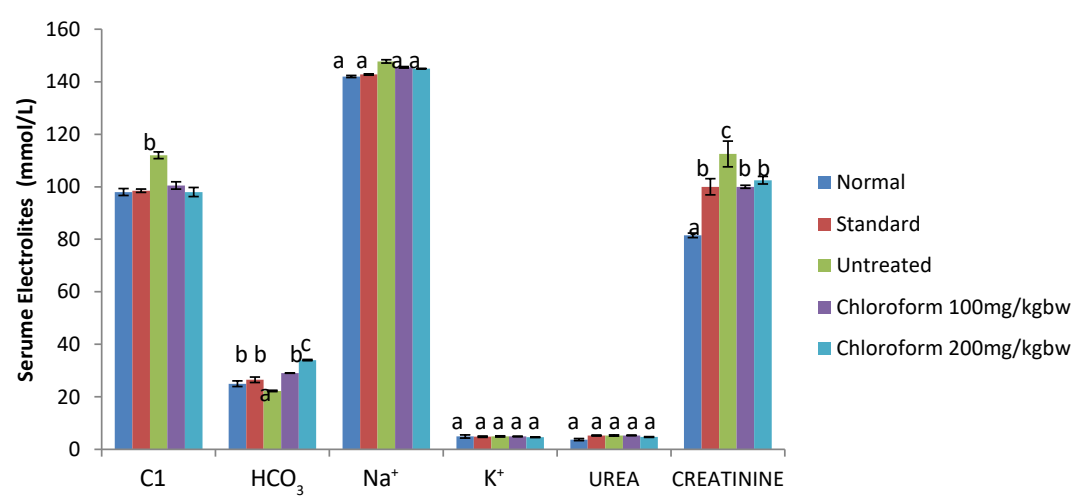

Figure 2. Effect of Chloroform extract of L. Hastata leaves on the electrolyte, urea and creatinine in adrenaline-induced hypertensive but untreated rats

$\mathrm{Cl}$ : Chloride Ion; $\mathrm{HCO}_{3}$ : Bicarbonate ion; $\mathrm{Na}^{+}$: Sodium Ion; $\mathrm{K}^{+}$: Potassium Ion. Bars with different superscript alphabets were significantly different $(c>b>a)$.

in adrenaline-induced hypertensive but untreated rats compared with the extract and amlodipine treated, and normal control groups.

\section{Discusion}

Medicinal herbs have been used as traditional medicines in Nigeria. Most herbs are relatively inexpensive and readily available, and have few adverse effects [7]. The present study examined the effects of L. Hastata extract on the biochemical parameters in adrenaline-induced hypertensive rats. The finding demonstrated that the induced hypertension stimulated hypercholesterolemia and hyperlipidemia, increased the liver enzymes, plasma electrolytes, and decreased the haematological parameters in rats.
The evaluation of serum enzyme biomarkers provides reliable indicators of the functional integrity of the liver and the treatment outcomes [21]. In the present study, the elevated levels of serum AST and ALP activities in the untreated rats were the indications of plasma membranes and hepatic cells impairments, which adversely hamper amino acids and carbohydrate metabolism, and impact the ATP production [22]. The administration of L. Hastata extract and amlodipine caused a significant restoration of the plasma membranes and liver functional integrity as evident by decreases in ALP and AST activities. The results suggest that the extract might partially protect various tissues, including liver cells, from the adrenalineinduced hypertension [23].

Table 1. Effect of the extract of L. Hastate leaves on the biochemical parameters in hypertensive rats

\begin{tabular}{|c|c|c|c|c|c|c|c|}
\hline \multirow{2}{*}{ Group } & \multicolumn{7}{|c|}{ Means $\pm S D$} \\
\hline & $\begin{array}{l}\text { Albumin } \\
\text { (mg/dL) }\end{array}$ & $\mathrm{TB}(\mathrm{mg} / \mathrm{dL})$ & $\mathrm{DB}(\mathrm{mg} / \mathrm{dL})$ & ALP (U/L) & ALT (U/L) & AST (U/L) & $\mathrm{TP}(\mathrm{mg} / \mathrm{dL})$ \\
\hline Normal & $3.97 \pm 0.1^{\mathrm{a}}$ & $13.50 \pm 1.4^{\mathrm{a}}$ & $3.12 \pm 0.3^{\mathrm{a}}$ & $26.5 \pm 2.8^{\mathrm{a}}$ & $42.75 \pm 1.1^{\mathrm{a}}$ & $97.75 \pm 1.0^{\mathrm{a}}$ & $6.47 \pm 0.2^{\mathrm{b}}$ \\
\hline Standard & $4.17 \pm 0.2^{b}$ & $13.50 \pm 1.3^{\mathrm{a}}$ & $3.2 \pm 0.4^{\mathrm{a}}$ & $36.78 \pm 2.7^{b}$ & $70.25 \pm 2.9^{c}$ & $97.05 \pm 0.7^{\mathrm{a}}$ & $7.02 \pm 0.4^{c}$ \\
\hline Untreated & $5.26 \pm 0.1^{c}$ & $14.25 \pm 0.8^{a}$ & $3.17 \pm 0.4^{\mathrm{a}}$ & $40.54 \pm 3.4^{c}$ & $73.56 \pm 1.0^{c}$ & $106.45 \pm 0.2^{b}$ & $5.57 \pm 0.8^{\mathrm{a}}$ \\
\hline $\begin{array}{c}\text { Extract } 100 \\
\mathrm{mg} / \mathrm{kg}\end{array}$ & $4.75 \pm 0.1^{b}$ & $14.50 \pm 1.3^{\mathrm{a}}$ & $3.20 \pm 0.0^{\mathrm{a}}$ & $37.53 \pm 0.9^{b}$ & $68.89 \pm 0.0^{b}$ & $93.56 \pm 0.4^{a}$ & $7.15 \pm 0.0^{c}$ \\
\hline $\begin{array}{c}\text { Extract } 200 \\
\mathrm{mg} / \mathrm{kg}\end{array}$ & $4.93 \pm 0.0^{b}$ & $14.50 \pm 1.2^{\mathrm{a}}$ & $3.30 \pm 0.0^{\mathrm{a}}$ & $28.78 \pm 5.2^{\mathrm{a}}$ & $75.78 \pm 0.6^{c}$ & $101.65 \pm 0.3^{a}$ & $6.85 \pm 0.0^{\mathrm{b}}$ \\
\hline
\end{tabular}

ALP: Alkaline Phosphatase; ALT: Alanine Aminotransferase; AST: Aspartate aminotransferase; TP: Total Protein; TB: Total Bilirubin; DB: Direct Bilirubin

Values with different superscript alphabets along the columns were significantly different $(\mathrm{P}<0.05)$ 
Table 2. Effect of the extract of L. Hastate leaves on lipid profile in hypertensive rats

\begin{tabular}{ccccc}
\hline & \multicolumn{4}{c}{ Means \pm SD } \\
\cline { 2 - 4 } Group & LDL-cholesterol $(\mathbf{m m o l} / \mathrm{L})$ & $\begin{array}{c}\text { HDL-cholesterol } \\
(\mathbf{m m o l} / \mathrm{L})\end{array}$ & Cholesterol $(\mathrm{mmol} / \mathrm{L})$ & Triglyceride (mmol/L) \\
\hline Normal & $2.45 \pm 0.1^{\mathrm{a}}$ & $1.475 \pm 0.1^{\mathrm{a}}$ & $3.77 \pm 0.1^{\mathrm{a}}$ & $2.93 \pm 0.2^{\mathrm{a}}$ \\
\hline Standard & $2.77 \pm 0.0^{\mathrm{a}}$ & $1.55 \pm 0.1^{\mathrm{a}}$ & $3.67 \pm 0.1^{\mathrm{a}}$ & $2.03 \pm 0.4^{\mathrm{a}}$ \\
\hline Untreated & $4.625 \pm 0.1^{\mathrm{b}}$ & $1.55 \pm 0.1^{\mathrm{a}}$ & $5.95 \pm 0.3^{\mathrm{b}}$ & $2.95 \pm 0.5^{\mathrm{a}}$ \\
\hline $\begin{array}{c}\text { Extract } \\
(100 \mathrm{mg} / \mathrm{kg})\end{array}$ & $2.85 \pm 0.1^{\mathrm{a}}$ & $1.43 \pm 0.0^{\mathrm{a}}$ & $3.90 \pm 0.0^{\mathrm{a}}$ & $2.67 \pm 0.4^{\mathrm{a}}$ \\
\hline \begin{tabular}{c} 
Extract $(200 \mathrm{mg} / \mathrm{kg})$ \\
\hline
\end{tabular} & $2.85 \pm 0.0^{\mathrm{a}}$ & $1.725 \pm 0.0^{\mathrm{a}}$ & $3.75 \pm 0.2^{\mathrm{a}}$ & $2.45 \pm 0.3^{\mathrm{a}}$ \\
\hline
\end{tabular}

Values with different superscript alphabets along the columns were significantly different $(\mathrm{P}<0.05)$

The total proteins, albumin and bilirubin levels represent the integrity of kidneys and liver [24]. The observed decreases in the total proteins concentration in the untreated rats could be attributed to decreases in various acute phase proteins, globulins and fibrinogen in hypertensive individuals [25]. The decline in total proteins, as reported in this study, could lead to impaired tissue hydration, which is injurious to cellular homeostasis. This negatively compromises the normal metabolic activities of the liver and consequently the health of the animals [26]. The significant decline in the albumin concentration in the untreated rats suggests the impaired liver function associated with cardiovascular disease [27].

Electrolyte imbalance and alteration in renin-angiotensin system play key roles in the pathogenesis of hypertension [28]. Plasma electrolytes, creatinine and urea concentrations are useful clinical indices of renal integrity [29]. Creatinine is a waste product of muscle metabolism while urea is a by-product of protein metabolism [21]. As a result of renal impairment, the excretion of these metabolites is altered by their accumulation in the blood [29].

The observed significant increase in serum creatinine concentration in the untreated rats is suggestive of renal impairment. The pathologic conditions must either alter the metabolism of creatinine leading to increased synthesis or decreased tubular excretion [12]. Furthermore, the significant alterations in the concentrations of sodium, bicarbonate and chloride suggest that the integrity of renal tubules had been compromised for the excretion of these metabolites in the rats [22]. Treatment of the hypertensive rats with $L$. Hastate significantly restored the normal levels of these metabolites thereby preserving the functional integrity of the kidneys in adrenaline-induced hypertensive rats. As L. Hastata extract prevented the hy- percreatinemia, it might also prevent the eventual disruption of glomerular filtration [28].

The increased levels in total cholesterol, triglyceride and LDL are indications of abnormal lipid metabolism and predisposition of the heart to atherosclerosis and coronary heart disease [30]. Thus, the assessment of lipid profile is crucial in the evaluation of the hypotensive properties of medicinal plants. Consequently, the cholesterol and LDL concentrations were significantly higher in adrenaline-induced hypertensive but untreated rats compared with the rats that were treated with either the extract or amlodipine.

The analyses of the hematological parameters provide vital information about the effect of toxins on the blood [31]. The significantly high levels of WBC and RBC counts, mean hemoglobin, and packed cell value following the treatment with the extract are indications of its beneficial haematopoietic effects [32].

\section{Conclusions}

The findings of the present study suggest that the treatment of adrenaline-induced hypertensive rats with the extract of $L$. Hastata leaves protects against renal, hepatic and cardiac injuries in this experimental animal model. Thus, the extract could be considered a natural product with anti-hypertensive properties. However, further studies are required to identify the bioactive constituents involved and to elucidate the mechanisms of action. 


\section{Ethical Considerations}

\section{Compliance with ethical guidelines}

The principles governing the use of laboratory animals as laid out by the Federal University of Technology, Minna Committee on Ethics for Medical and Scientific Research also existing internationally accepted principles for laboratory animal use and care as contained in the Canadian Council on Animal Care Guidelines and Protocol Review were duly observed.

\section{Funding}

This research did not receive any specific grant from funding agencies in the public, commercial, or not-for-profit sectors

\section{Author's contributions}

All authors contributed in preparing this article.

\section{Conflict of interest}

The authors declared no conflict of interest.

\section{Acknowledgements}

The authors would like to appreciate the technical staff of the Biochemistry Department of the Federal University of Technology, Minna, Nigeria, for their kind assistances.

\section{References}

[1] Patel P, Vaghasiya J, Thakor A, Jariwala J. Antihypertensive effect of rhizome part of Acorus calamus on renal artery occlusion induced hypertension in rats. Asian Pac J Trop Dis. 2012; 2(suppl. 1): S6-S10. [DOI:10.1016/S2222-1808(12)60114-5]

[2] Ara N, Rashid M, Amran MS. Comparison of hypotensive and hypolipidemic effects of catharanthus roseus leaves extract with nifedipine in adrenaline-induced hypertensive rats. J Biol Sci. 2008; 8(6):1082-6. [DOI:10.3923/jbs.2008.1082.1086]

[3] World Health Organization (WHO). World Health Statistics 2012. Geneva: WHO Press; 2012

[4] James O, Friday EA, Unekwuojo EG. Antihypertensive effect of methanol extract of Napoleona imperialis (P. Beauv) in adrenaline-induced hypertensive albino rats. Int J Biochem Res Rev. 2011; 1(2):47-57. [DOI:10.9734/IJBCRR/2011/274

[5] LLawal B, Shittu OK, Inje OF, Berinyuy EB, Muhammed H. African natural product with potential antioxidants and hepatoprotective properties: A review. Clin Phytosci. 2017; 2(23):1-66. [DOI:10.1186/s40816-016-0037-0]
[6] James PA, Oparil S, Carter BL, Cushman WC, DennisonHimmelfarb C, Handler J, et al. Evidence-based guideline for the management of high blood pressure in adults: Report from the panel members appointed to the Eighth Join National Committee (JNC 8). JAMA. 2014; 311(5):507-20. [DOI:10.1001/jama.2013.284427] [PMID]

[7] Umaru IJ, Fasihuddin BA, Hauwa AU, Kerenhappuch IU. Leptadenia hastata (pers) decne: Phytochemical, pharmacological, biotechnological, botanical, traditional use and agronomical aspects. Eur J Pharm Med Res. 2018; 5(6):109-19.

[8] Togola A, Austarheim I, Theïs A, Diallo D, Paulsen BS. Ethnopharmacological uses of Erythrina senegalensis: A comparison of three areas in Mali, and a link between traditional knowledge and modern biological science. J Ethnobiol Ethnomed. 2008; 4:6. [DOI:10.1186/1746-4269-4-6] [PMID] [PMCID]

[9] Betti JL, Yemefa'a SR, Nchembi M, Tarla, F. Contribution to the knowledge of non-wood forest products of the far north region of Cameroon: Medicinal plants sold in the Kousséri market. J Ecol Nat Envir. 2011; 3(7): 241-54.

[10] Dambatta SH, Aliyu BS. A survey of major ethnomedicinal plants of Kano North Nigeria, their knowledge and uses by traditional healers. Bayero J Pure Appl Sci. 2011; 4(2): 28-34.

[11] Bello A, Aliero AA, Saidu Y, Muhammad S. PhytochemicalScreening, polyphenolic content and alpha-glucosidase inhibitory potential of leptadenia hastata (pers.) decne. Niger J of Bas ApplScience. 2011; 19(2): 181-6.

[12] Onukogu SC, Tsado AN, Muhammad FM, Alawode RA, Suleiman A, Ojo OP, et al. In vitro antioxidants, antimicrobials and biochemical response of methanol leaf extract of eucalyptus camaldulensis following sub-acute administration to rats. Saudi J Biomed Res. 2019; 4(11): 405-11. [DOI:10.36348/ SJBR]

[13] Yusuf AA, Lawal B, Yusuf MA, OmonijeYO, Adejoke AA, Raji FH, et al. Free radical scavenging, antimicrobial activities and effect of sub-acute exposure to Nigerian Xylopia Aethiopica seed extract on liver and kidney functional indices of Albino Rats. Iran J Toxicol. 2018; 12(3):51-8.

[14] Reitman S, Frankel S. A colorimetric method for the determination of serum glutamic oxalacetic and glutamic pyruvic transaminases. Am J Clin Pathol. 1957; 28(1):56-63. [DOI:10.1093/ajcp/28.1.56] [PMID]

[15] Gornall AC, Bardawill CJ, David MM. Determination of serum protein by means of biuret reaction. J Biol Chem. 1949; 177: 751-66.

[16] Doumas BT, Watson WA, Biggs HG. Albumin standards and the measurement of serum albumin with bromocresol green. Clin Chem Acta. 1971; 31(1):87-96. [DOI:10.1016/00098981(71)90365-2]

[17] Blass KG, Thierbert RJ, Lam LK. A study of the mechanism of the Jaff'e reaction. Z Klin Chem Klin Biochem. 1974; 12(7):336-43. [DOI:10.1515/cclm.1974.12.7.336] [PMID]

[18] Tietz NW. Clinical guide to laboratory tests. $3^{\text {rd }}$ ed. Philadelphia: WB Saunders Company; 1995.

[19] Friedewald WT, Levy RI, Fredrickson DS. Estimation of the concentration of low-density lipoprotein cholesterol in plasma, without use of the preparative ultracentrifuge. Clin Chem. 1972; 18(6): 499-502. [DOI:10.1109/TIT.1972.1054846] 
[20] Dacie JV, Lewis SM. Practical haematology, 11th Ed. London: Elsevier; 2002.

[21] Yusuf AA, Lawal B, Abubakar AN, Berinyuy EB, Omonije YO, Umar SI, et al. In-vitro antioxidants, antimicrobial and toxicological evaluation of Nigerian Zingiber officinale. Clin Phytosci. 2018; 4(12):1-8 [DOI:10.1186/s40816-018-0070-2]

[22] Lawal B, Shittu OK, Oibiokpa IF, Mohammed H, Umar SI, Haruna GM. Antimicrobial evaluation, acute and sub-acute toxicity studies of Allium sativum. J Acute Dis. 2016; 5(4):296301. [DOI:10.1016/j.joad.2016.05.002]

[23] Bopda MOS, Dimo T, Tonkep SI, Zapfack L, Zeufiet DD, Kamtchouing P. Cardio depression as a possible mechanism of the hypotensive effect in rats. Afr J Biotechnol. 2011; 10(72):16393-401.

[24] Zilva JF, Panmall PR, Mayne PD. Clinical chemistry in diagnosis and treatment, $5^{\text {th }}$ edition. England: Ives Plc.; 1991.

[25] Shittu OK, Lawal B, Alozieuwa BU, Haruna GM, Abubakar AN, Berinyuy EB. Alteration in biochemical indices following chronic administration of methanolic extract of Nigeria bee propolis in Wister rats. Asian Pac J Trop Dis. 2015; 5(8):654-7. [DOI:10.1016/S2222-1808(15)60907-0]

[26] Shittu OK, Lawal B, Alozieuwa BU, Haruna GM, Abubakar AN, Berinyuy EB. Antioxidant activities of giant african snail (achachati namaginata) haemolymph against ccl4- induced hepatotoxicity in albino rats. Br J Pharmac Res. 2015; 6(3):141-54. [DOI:10.9734/BJPR/2015/15887]

[27] Libor V. The role of bilirubin in diabetes, metabolic syndrome, and cardiovascular diseases. Front Pharmacol. 2012; 3:55-61. [DOI:10.3389/fphar.2012.00055]

[28] Vadivel K, Thangabalan B, Rafi SK, Manohar Babu S. Cardiovascular effects of aqueous leaf extract of Aristolochia bracteata lam, on isolated perfused frog heart preparation. Int J Phytopharmacol. 2013; 4(2):93-8.

[29] Umar SI, Ndako M, Jigam AA, Adefolalu SF, Ibikunle GF, Lawal B. Anti-plasmodial, anti-inflammatory, anti-nociceptive and safety profile of Maytenus senegalensis root bark extract on hepatorenal integrity in experimental animals. Comp Clin Pathol. 2019; 28:1571-9. [DOI:10.1007/s00580-019-02965-4]

[30] Ladei A, Stefanelli E, Ladeia-frota C, Moreira A, Hiltner A, Adan L. Association between elevated serum C-reactive protein and triglyceride levels in young subjects with type-1 diabetes. Diabetes Care. 2006; 29:424-6. [DOI:10.2337/diacare.29.02.06.dc05-2033] [PMID]

[31] Berinyuy EB, Lawal B, Olalekan AA, Olalekan AA, Yusuf AA, Sakpe S, et al. Hematological status and organs/bodyweight parameters in wister rats during chronic administration of cassia occidentalis. Int Blood Res Rev. 2015; 4(3):1-7. [DOI:10.9734/IBRR/2015/22021]

[32] Lawal B, Shittu OK, Abubakar AN, Haruna GM, Sani S, Ossai PC. Haematopoetic effect of methanol extract of Nigerian honey bee (Apismellifera) propolis in mice. J Coastal Life Med. 2015; 3(8):648-51. [DOI:10.12980/JCLM.3.2015J5-89] 
This Page Intentionally Left Blank 